\title{
Membrane-Based Extraction of Nickel(II) Using the Mixture Acorga M5640 and DP-8R as Carrier
}

\author{
Francisco José Alguacil,* Manuel Alonso and Aurora López-Delgado \\ Centro Nacional de Investigaciones Metalúrgicas (CSIC), Avda. Gregorio del Amo 8, Ciudad Universitaria, \\ 28040 Madrid, Spain
}

\begin{abstract}
Um estudo experimental sobre transporte de Ni(II) através de uma membrana líquida suportada em folha plana usando a mistura de Acorga M5640 e DP-8R como transportador, foi realizado a $20^{\circ} \mathrm{C}$. O sistema de transporte foi estudado como uma função de muitas variáveis: velocidade de agitação das fases alimentadora (400-2000 $\left.\mathrm{min}^{-1}\right)$ e receptora (400$\left.1500 \mathrm{~min}^{-1}\right)$, concentração de ácido $\left(2,5 \times 10^{-1}\right.$ a $1,0 \mathrm{~mol} \mathrm{~L}{ }^{-1}$ de ácido sulfúrico) na fase receptadora, $\mathrm{pH}$ da fase de alimentação (2 a 5), diluente da membrana e carregador $(2,5 \%$ $\mathrm{v} / \mathrm{v}$ a $20 \% \mathrm{v} / \mathrm{v}$, de cada reagente) e concentrações do metal $\left(1,7 \times 10^{-4}\right.$ a $\left.1,4 \times 10^{-3} \mathrm{~mol} \mathrm{~L}^{-1}\right)$ na membrana e na fase de alimentação, respectivamente. Nas condições experimentais atuais, o processo de transporte é controlado pela difusão do níquel dentro do filme estacionário da fase de alimentação, onde o coeficiente de transferência de massa e a espessura do filme aquoso são estimados como $1,21 \times 10^{-3} \mathrm{~cm} \mathrm{~s}^{-1}$ e $8,3 \times 10^{-3} \mathrm{~cm}$, respectivamente.
\end{abstract}

An experimental study of $\mathrm{Ni}(\mathrm{II})$ transport through a flat-sheet supported liquid membrane using the mixture of Acorga M5640 and DP-8R as carrier was performed at $20^{\circ} \mathrm{C}$. The transport system was studied as a function of several variables: stirring speed of the feed $\left(400-2000 \mathrm{~min}^{-1}\right)$ and receiving (400-1500 $\left.\mathrm{min}^{-1}\right)$ phases, concentration of the strippant $\left(2.5 \times 10^{-1}\right.$ to $1.0 \mathrm{~mol} \mathrm{~L}^{-1}$ sulfuric acid) in the receiving phase, $\mathrm{pH}$ of the feed phase (2 to 5), diluent of the membrane and carrier $\left(2.5 \% \mathrm{v} / \mathrm{v}\right.$ to $20 \% \mathrm{v} / \mathrm{v}$, each reagent) and metal $\left(1.7 \times 10^{-4}\right.$ to $\left.1.4 \times 10^{-3} \mathrm{~mol} \mathrm{~L}^{-1}\right)$ concentrations in the membrane and feed phases, respectively. Under the present experimental conditions, the transport process is controlled by diffusion of nickel species in the stagnant film of the feed phase, whereas the mass transfer coefficient and the thickness of the aqueous film are estimated as $1.21 \times 10^{-3} \mathrm{~cm} \mathrm{~s}^{-1}$ and $8.3 \times 10^{-3} \mathrm{~cm}$, respectively.

Keywords: membrane transport, nickel (II), acorga M5640, DP-8R

\section{Introduction}

Whereas membrane technologies are one of the most important topics in today's research and practical use, liquid membrane processes have been proposed as clean ones owing to their characteristics of high specificity, low energy utilisation, the extraction and stripping steps are combined in a single operation etc.; thus, the use of liquid membranes has gained a general interest in the treatment of effluents were solute concentrations are low and large volume of solutions must be processed, and if possible, without generating any secondary waste.

Accordingly, these liquid membrane technologies comply with the PARCOM (The Paris Commission

*e-mail: fjalgua@cenim.csic.es
Recommendation on Best Available Techniques and Best Environmental Practice) requirements. ${ }^{1}$

It is considered that membrane technologies may compete favourably with other most common technologies, i.e. precipitation, solvent extraction, ion exchange etc., in the treatment of liquid effluents. Including in liquid membrane technologies, supported liquid membranes configurations include flat-sheet, hollow fiber and spiral wound; it is recognized that if the former is useful for first laboratory data, both the latter are more adequate for industrial use since they provide higher surface area to volume ratio.

Among the metals found in liquid streams, nickel appeared. Nickel in surface water arises from various sources: soil and tailing piles, landfill leachates, atmospheric deposition and industrial and municipal wastewaters. In the general population, ingestion of nickel- 
containing foodstuffs represents the primary route of nickel exposure, and, though there is not an apparent EPAmandated legal limit on the amount of nickel in drinking water, the recommendation of the agency is of a maximum contaminant level of $1.7 \times 10^{-3} \mathrm{~mol} \mathrm{~L} \mathrm{~L}^{-1}$. The toxicological character of nickel to humans is related to that the ingestion of this element, both in soluble and non-soluble forms, is consistently associated, among others, with lung and nasopharyngeal cancer. ${ }^{2}$

In previous works, the extraction of nickel (II) from aqueous solutions using various mixtures of acidic reagents were studied. ${ }^{3-5}$ The performance of these extractants mixtures on nickel extraction, i.e. allowing the metal extraction at more acidic values than each separate reagent, had led to implement one of these extraction systems in a supported liquid membrane design in order to investigate the nickel transport using the mixture of Acorga M5640 and DP-8R extraction reagents in Exxsol D100 as mobile carrier phase.

Moreover, liquid membranes were used in nickel transport, ${ }^{1,6-9}$ with few data on the use of these extractants mixtures on nickel permeation and with no data available in the literature about the use of this particular mixture (Acorga M5640 and DP-8R).

In the present work, a flat-sheet membrane configuration has been investigated to obtain data on the transport of nickel using the mixture Acorga M5640 (oxime derivative) and DP-8R (organophosphoric acid) as carrier. Various experimental conditions, which influence the metal transport were studied, and conditions for the nickel removal from the aqueous solution were also established.

\section{Experimental}

The extractants used in this work had the following specifications.

The active substance of DP-8R is di(2-ethylhexyl) phosphoric acid, its purity was found to be $>97 \%$ by potentiometric titration with $\mathrm{NaOH}$ in ethanol medium. ${ }^{10}$

Alkylsalicylaldehide oxime derivatives, such as Acorga M5640, belong to the fourth group of hydroxyoxime extractants and form the second generation of such reagents. ${ }^{11}$ The active substance of Acorga M5640 is 2-hydroxy-5-nonylbenzaldehyde oxime to which a fatty ester is added as a modifier.

DP-8R and Acorga M5640 extractants were supplied by Daihachi and Avecia, respectively. Both extractants were used as supplied by the manufacturers as also did with Exxsol D100 diluent (ExxonMobil Chem. Iberia, Spain) containing $>99 \%$ aliphatics, boiling range 234 -
$264{ }^{\circ} \mathrm{C}$, flash point $99{ }^{\circ} \mathrm{C}$ and Solvesso 100 diluent (ExxonMobil Chem. Iberia, Spain) containing > 99\% aromatics, boiling range $167-178{ }^{\circ} \mathrm{C}$ and flash point 48 ${ }^{\circ} \mathrm{C}$; all other chemicals were of AR grade.

The organic membrane phase was prepared by dissolving the corresponding volume of Acorga M5640 and DP-8R in the organic diluent to obtain carrier solutions of different concentrations. The polymeric support was impregnated with the carrier solution by immersion for $24 \mathrm{~h}$ (previous experiments had shown that longer immersion times do not enhance metal transport), then leaving it to drip for $10 \mathrm{~s}$ before being placed in the flat-sheet supported liquid membrane cell. The support used was Millipore Durapore GVHP4700 (polyvinylidenefluoride) of $125 \times 10^{-4} \mathrm{~cm}$ thickness, nominal porosity of $75 \%$, effective pore size of 0.22 $\mu \mathrm{m}$ and tortuosity 1.67 .

Batch liquid membrane measurements were carried out with a two-compartment permeation cell, which consisted of a feed phase $\left(200 \mathrm{~cm}^{3}\right)$ separated from a receiving phase chamber $\left(200 \mathrm{~cm}^{3}\right)$ by the liquid membrane having an effective membrane area of 11.3 $\mathrm{cm}^{2}$. Both the feed and receiving phases were stirred mechanically at $1500 \mathrm{~min}^{-1}$ (unless stated otherwise) at $20{ }^{\circ} \mathrm{C}$ to avoid concentration polarisation conditions at the membrane interfaces and in the bulk of the solutions. Agitation was performed in both compartments by using cylindrical Teflon impellers having a diameter of $2.4 \mathrm{~cm}$. Metal transport was determined by monitoring nickel concentrations by atomic absorption spectrometry (AAS) in the feed and receiving phases as a function of time. The metal concentration in the various phases was found to be reproducible within $98 \%$ accuracy. The flux was determined by the following equation,

$\mathrm{J}=\frac{[\mathrm{Ni}(\mathrm{II})] \mathrm{V}}{\mathrm{A} \Delta \mathrm{t}}$

where $[\mathrm{Ni}(\mathrm{II})]$ represents the change in the nickel concentration at an elapsed time period in the feed or receiving phases, $\mathrm{V}$ is the volume of solution in the feed or receiving phases, $\mathrm{A}$ is the effective membrane area and $\Delta \mathrm{t}$ represent time interval. The fluxes values shown in Tables 1-5 where determined in the feed side, whereas the accuracy of the fluxes values determined within this work is estimated as \pm 0.02 .

\section{Results and Discussion}

In acidic aqueous sulfate media the extraction of nickel (II) using the mixture of DP-98R $\left(\mathrm{H}_{2} \mathrm{~L}_{2}\right)$ and Acorga 
M5640 (HR) is based on the following and general cationic exchange reaction:

$\mathrm{Ni}_{\mathrm{aq}}^{2+}+\mathrm{p}\left(\mathrm{H}_{2} \mathrm{~L}_{2}\right)_{\text {org }}+\mathrm{q}(\mathrm{HR})_{\text {org }} \Leftrightarrow \mathrm{Ni}\left(\mathrm{L}_{2 \mathrm{p}} \mathrm{R}_{\mathrm{q}} \mathrm{H}_{2 \mathrm{p}+\mathrm{q}-2}\right)_{\text {org }}+2 \mathrm{H}_{\mathrm{aq}}^{+}$

where the coefficients $\mathrm{p}$ and $\mathrm{q}$ take the value of 2, 4 (p) and 2 (q). It can also be pointed out that the oxime reagent is amenable to dimerize (HR) $)_{2}$, thus, from the above it can be conclude that various species with different stoichiometries can be found in the organic phase. ${ }^{12}$ However, and though the metal extraction chemistry is identical to that found in solvent extraction, in supported liquid membranes processing the overall is governed by kinetic rather than equilibrium parameters.

\section{Influence of stirring speed in the feed and receiving phases}

The influence of the stirring speed of the aqueous feed solutions on the transport of $\mathrm{Ni}(\mathrm{II})\left(1.7 \times 10^{-4} \mathrm{~mol} \mathrm{~L}^{-1}\right)$ at $\mathrm{pH}$ $3.0 \pm 0.05$ with mixtures of Acorga M5640 (20\% v/v) and DP-8R (20\% v/v) in Exxsol D100 is shown in Table 1. As the stirring speed is increased to $1500 \mathrm{~min}^{-1}$, the thickness of the aqueous boundary layer near to the membrane feed interface is minimized to a near constant value, which resulted in the highest metal flux. Further, decrease in metal transport is noted with an increase in stirring speed owing to the high turbulence caused by stirring, resulting in a displacement of carrier phase from the membrane pore.

The variation of the stirring speed in the receiving phase also has an effect on metal transport, decreasing it as the stirring speed decreases.

Therefore, a stirring speed of $1500 \mathrm{~min}^{-1}$ was selected in the feed and receiving phases in order to avoid concentration polarization conditions in the aqueous phases.

Table 1. Influence of stirring speed on nickel transport

\begin{tabular}{ccc}
\hline $\begin{array}{c}\text { Feed phase } \\
\left( \pm 5 \mathrm{~min}^{-1}\right)\end{array}$ & $\begin{array}{c}\text { Receiving phase } \\
\left( \pm 5 \mathrm{~min}^{-1}\right)\end{array}$ & $\begin{array}{c}\mathrm{J} / \\
\left(10^{-10} \mathrm{~mol} \mathrm{~cm}^{-2} \mathrm{~s}^{-1}\right)\end{array}$ \\
\hline 1500 & 1500 & 1.89 \\
750 & 750 & 1.64 \\
1500 & 400 & 1.64 \\
750 & 400 & 1.33 \\
400 & 1500 & 1.33 \\
1750 & 1500 & 1.87 \\
2000 & 1500 & 1.67 \\
\hline
\end{tabular}

Receiving phase: $5.1 \times 10^{-1} \mathrm{~mol} \mathrm{~L}^{-1}$ sulfuric acid.

\section{Influence of the receiving phase composition}

The variation in the composition of the receiving phase $\left(\mathrm{H}_{2} \mathrm{SO}_{4}\right.$ from $2.5 \times 10^{-1}$ to $\left.1.0 \mathrm{~mol} \mathrm{~L}^{-1}\right)$ on nickel (II) transport was studied using a feed phase of $1.7 \times 10^{-4} \mathrm{~mol}$
$\mathrm{L}^{-1} \mathrm{Ni}(\mathrm{II})$ at $\mathrm{pH} 4.0 \pm 0.05$ and an organic phase of Acorga M5640 (10\% v/v) and DP-8R (10\% v/v) in Exxsol D100. Results obtained showed that this variation in the composition of the receiving phase has a negligible effect on nickel flux $\left(2.06 \times 10^{-10} \mathrm{~mol} \mathrm{~cm}^{-2} \mathrm{~s}^{-1}\right)$.

Nickel distribution profiles in the three phases during a transport experiment are shown in Figure 1. In the initial stages of the test, the decrease in nickel concentration in the feed phase was accompanied by a corresponding increase in the membrane concentration. There was a delay time before nickel was transferred from the membrane to the receiving phase. The receiving phase concentration then increases with time and after about $50 \mathrm{~min}$, nickel was being transported from dilute to concentrated solution, driven by the counter-transport of the counter-ion from the receiving to the feed phase.

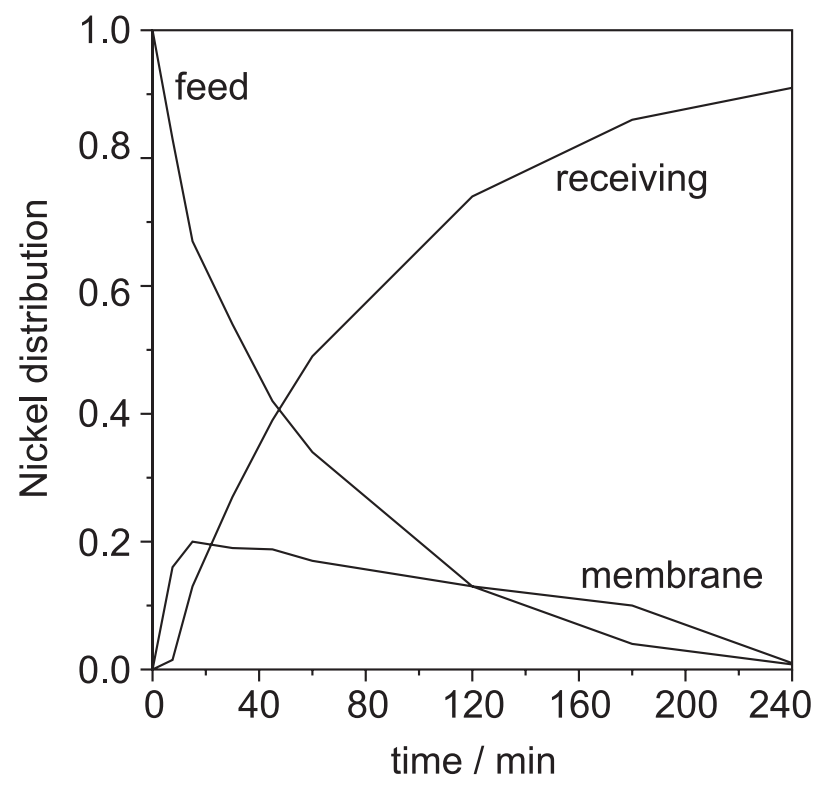

Figure 1. Nickel distribution profiles. Aqueous feed: $1.7 \times 10^{-4} \mathrm{~mol} \mathrm{~L}^{-1}$ $\mathrm{Ni}(\mathrm{II})$ at $\mathrm{pH} 4.0 \pm 0.05$. Membrane phase: Acorga M5640 (10\% v/v) and DP-8R (10\% v/v) in Exxsol D100. Receiving phase: $1.0 \mathrm{~mol} \mathrm{~L}^{-1} \mathrm{H}_{2} \mathrm{SO}_{4}$.

Table 2. Influence of initial $\mathrm{pH}$ on nickel transport

\begin{tabular}{cc}
\hline $\mathrm{pH} \pm 0.05$ & $\mathrm{~J} /\left(10^{-10} \mathrm{~mol} \mathrm{~cm}^{-2} \mathrm{~s}^{-1}\right)$ \\
\hline 2.0 & no transport \\
3.0 & 1.89 \\
4.0 & 1.99 \\
5.0 & 1.99 \\
\hline
\end{tabular}

Feed phase: $1.7 \times 10^{-4} \mathrm{~mol} \mathrm{~L}^{-1}$ nickel.

\section{Influence of feed phase $\mathrm{pH}$}

In the present supported liquid membrane system, the $\mathrm{pH}$ gradient between feed and receiving phases is one of the important driving forces for the transport of nickel. In order to assess the role of feed phase $\mathrm{pH}, \mathrm{pH}$ variation 
studies in the range 2.0-5.0 were carried out. The receiving phase consisted of $5.1 \times 10^{-1} \mathrm{~mol} \mathrm{~L}^{-1}$ sulfuric acid, whereas the concentration of the membrane carrier was Acorga M5640 (20\% v/v) and DP-8R (20\% v/v) in Exxsol D100. It is evident from Table 2 that the flux of nickel increases with an increase in $\mathrm{pH}$ from 2.0 to 4.0, although at higher $\mathrm{pH}$ it remained unaffected. Furthermore, at high $\mathrm{pH}$ values the diffusion of carrier through the membrane becomes ratedetermining, ${ }^{13}$ being the flux independent of $\mathrm{pH}$.

$\mathrm{J}=\frac{[\mathrm{Ni}(\mathrm{II})] \cdot \mathrm{V}}{\mathrm{A} \cdot \Delta \mathrm{t}}$

In the above equation, $\mathrm{J}$ is the metal flux, $[\mathrm{Ni}(\mathrm{II})]_{\mathrm{TOT}}$ is the total nickel concentration in the feed phase, and $\Delta_{\text {aq }}$ is the transport resistance due to diffusion by the aqueous feed boundary layer.

\section{Influence of nickel concentration}

Table 3 shows the variation of the nickel flux against the concentration of nickel ranging from $1.7 \times 10^{-4}$ to $1.4 \times$ $10^{-3} \mathrm{~mol} \mathrm{~L}^{-1}$ in the feed phase. At these nickel concentrations, the metal flux is a strong function of the initial nickel concentration in the feed phase. Hence, the transport process is controlled by diffusion of nickel species, and the permeation rate increases with increasing the nickel concentration. It is also expected that the flux should further increases and reach a limit corresponding to the loading capacity of the organic phase on feed side in the membrane, though this condition was not reached within the experimental conditions presented within this investigation.

Table 3. Influence of initial concentration of nickel (II) on metal transport

\begin{tabular}{cc}
\hline$[\mathrm{Ni}(\mathrm{II})]_{0} /\left(\mathrm{mol} \mathrm{L}^{-1}\right)$ & $\mathrm{J} /\left(10^{-9} \mathrm{~mol} \mathrm{~cm}^{-2} \mathrm{~s}^{-1}\right)$ \\
\hline $1.7 \times 10^{-4}$ & 0.19 \\
$3.4 \times 10^{-4}$ & 0.31 \\
$6.8 \times 10^{-4}$ & 0.79 \\
$1.4 \times 10^{-3}$ & 1.59 \\
\hline
\end{tabular}

Feed phase: solutions at $\mathrm{pH} 4.0 \pm 0.05$. Membrane phase: Acorga M5640 $(20 \% \mathrm{v} / \mathrm{v})$ and DP-8R (20\% v/v) in Exxsol D100. Receiving phase: $5.1 \times$ $10^{-1} \mathrm{~mol} \mathrm{~L}^{-1}$ sulfuric acid.

\section{Influence of carrier mixture concentration}

The carrier plays a decisive role in making the supported liquid membrane design efficient and economically viable. Thus, it is essential to evaluate the effect of carrier concentration on the transport of nickel. A supported liquid membrane having no carrier immobilized on the support results in no transport of nickel. The influence of Acorga M5640 and DP-8R concentration on metal flux was studied from 2.5 to $20 \%$ v/v (each reagent) in Exxsol D100. As can be seen from Table 4, the flux of nickel increases with carrier concentration up to $10 \% \mathrm{v} / \mathrm{v}$ (each) and then decreases. These results can be assumed by considering that diffusion in the organic membrane is negligible as compared with that for aqueous diffusion and that the transport process is controlled by the diffusion in the stagnant film of the aqueous feed phase. ${ }^{14}$ In this condition,

$\mathrm{J}_{\lim }=\frac{\mathrm{D}_{\mathrm{aq}}}{\mathrm{d}_{\mathrm{aq}}}[\mathrm{Ni}(\mathrm{II})]_{\text {rOT }}$

and assuming a value in the range of $10^{-5} \mathrm{~cm}^{2} \mathrm{~s}^{-1}$ for the aqueous diffusion coefficient of the nickel-containing species $\left(D_{\text {aq }}\right.$ ) and $J_{\lim }$ equal to $2.06 \times 10^{-10} \mathrm{~mol} \mathrm{~cm}^{2} \mathrm{~s}^{-1}$, the thickness of the aqueous diffusion film $\left(\mathrm{d}_{\mathrm{aq}}\right)$ estimated from the above equation is $8.3 \times 10^{-3} \mathrm{~cm}$. This value is the minimum thickness of the stagnant aqueous diffusion layer in the present experimental conditions. The decreasing in the metal transport at higher carrier concentrations can be attributable to an increase of the membrane phase viscosity, which results in a decrease of the diffusion coefficient in the membrane. On the other hand, by considering equation 3 and from equation 4 , the mass transfer coefficient in the aqueous phase $\left(1 / \Delta_{\mathrm{aq}}\right)$ is estimated as $1.21 \times 10^{-3} \mathrm{~cm} \mathrm{~s}^{-1}$.

Table 4. Metal flux versus carrier mixture concentration

\begin{tabular}{cc}
\hline Acorga M5640+DP-8R / $(\% \mathrm{v} / \mathrm{v})$ & $\mathrm{J} /\left(10^{-10} \mathrm{~mol} \mathrm{~cm}^{-2} \mathrm{~s}^{-1}\right)$ \\
\hline $2.5+2.5$ & 1.39 \\
$5+5$ & 1.94 \\
$10+10$ & 2.06 \\
$20+20$ & 1.99 \\
\hline
\end{tabular}

Feed phase: $1.7 \times 10^{-4} \mathrm{~mol} \mathrm{~L}^{-1} \mathrm{Ni}(\mathrm{II})$ at $\mathrm{pH} 4.0 \pm 0.05$. Receiving phase: 5.1 $\times 10^{-1} \mathrm{~mol} \mathrm{~L}^{-1}$ sulfuric acid.

Table 5 shows that at the same $\mathrm{pH}$ value the transport of nickel by the mixed extractants is enhanced over the performance of the two single extractants, especially in the case of Acorga M5640, and thus confirming the synergistic effect of the mixture.

Table 5. Nickel transport using Acorga M5640, DP-8R or a mixture of both reagents

\begin{tabular}{ll}
\hline \multicolumn{1}{c}{ Carrier phase } & $\mathrm{J} /\left(10^{-10} \mathrm{~mol} \mathrm{~cm}^{-2} \mathrm{~s}^{-1}\right)$ \\
\hline Acorga M5640 (40\% v/v) & 1.21 \\
DP-8R (40\% v/v) & 1.97 \\
Acorga M5640 (20\% v/v)+DP-8R (20\% v/v) & 1.99 \\
\hline
\end{tabular}

Feed phase: $1.7 \times 10^{-4} \mathrm{~mol} \mathrm{~L}^{-1} \mathrm{Ni}(\mathrm{II})$ at $\mathrm{pH} 4.0 \pm 0.05$. Receiving phase: $5.1 \times 10^{-1} \mathrm{~mol} \mathrm{~L}^{-1}$ sulfuric acid. 


\section{Influence of organic phase diluent}

The importance of the correct diluent choice had been long recognized in extraction processes and, since the membrane organic phase consisted basically of an extractant and a diluent, it is also recognized that the organic diluent may influences the performance of liquid membrane systems. ${ }^{15,16}$

To determine its effect on the present system, experiments were carried out with solutions of Acorga M5640 (10\% v/v) and DP-8R (10\% v/v) in each diluent and feed phases of $1.7 \times 10^{-4} \mathrm{~mol} \mathrm{~L}^{-1} \mathrm{Ni}$ (II) at $\mathrm{pH} 4.0 \pm 0.05$; the receiving phase was of $5.1 \times 10^{-1} \mathrm{~mol} \mathrm{~L}^{-1}$ sulfuric acid. Table 6 shows the corresponding metal fluxes for each diluent used in the investigation. The change in the organic diluent has some effect on the transport of nickel. Thus, transport using the carrier mixture of Acorga M5640 and DP-8R is enhanced using organic diluents of aliphatic nature and somewhat lower viscosity since the diffusion coefficient in the membrane decreases with an increase of the viscosity of the diluent, though it is difficult to ascribe the transport of the metal to any particular property of the organic diluent.

In the case of all the diluents tested in the present work, the somewhat lower fluxes measured at the receiving side suggests that membrane resistance is of less importance and that the stripping reaction kinetics may play a significant role in the transport of nickel. In all the cases, the metal transport against the gradient of the same ion is observed after approximately $1 \mathrm{~h}$.

Table 6. The effect of membrane diluent on nickel flux

\begin{tabular}{lcc}
\hline Diluent & ${ }^{\mathrm{a}} /\left(10^{-10} \mathrm{~mol} \mathrm{~cm} \mathrm{cs}^{-1}\right)$ & $\mathrm{b} /\left(10^{-10} \mathrm{~mol} \mathrm{~cm}^{-2} \mathrm{~s}^{-1}\right)$ \\
\hline Cumene & 2.03 & 1.95 \\
Solvesso 100 & 2.03 & 1.97 \\
n-Decane & 2.04 & 2.02 \\
Exxsol D100 & 2.06 & 1.91
\end{tabular}

${ }^{\mathrm{a}}$ Feed side. ${ }^{\mathrm{b}}$ Receiving side.

\section{Conclusions}

The transport of nickel (II) from sulfate aqueous solutions through a flat-sheet supported liquid membrane containing the mixture Acorga M5640 and DP-8R have been investigated. The metal transport is influenced by a number of variables, i.e. the $\mathrm{pH}$ of the feed phase, extractants mixture and metal concentrations etc. Conditions for the nickel transport were established as: $\mathrm{pH}$ of the feed phase around 4.0, extractants mixture concentration at Acorga M5640 (10\% v/v) and DP-8R $(10 \% \mathrm{v} / \mathrm{v})$ and using an aliphatic diluent, sulfuric acid concentration in the receiving phase in the $2.5 \times 10^{-1}$ to 1.0 mol L ${ }^{-1}$ range. From experimental results, the mass transfer coefficient in the aqueous phase is found to be $1.21 \times 10^{-3}$ $\mathrm{cm} \mathrm{s}^{-1}$ and the thickness of the aqueous feed boundary layer is $8.3 \times 10^{-3} \mathrm{~cm}$. By no doubt, the efficiency of the transport process can be improved by using a more effective membrane unit, i.e. hollow fiber modules.

\section{Acknowledgments}

Authors thank the CSIC (Spain) for support to carry out this work and Mr. J. L. Bascones and Mr. López for their technical assistance.

\section{References}

1. Van de Voorde, I.; Pinoy, L.; De Ketelaere, R. F.; J. Membr. Sci. 2004, 234, 11.

2. Sutherland, J. E.; Costa, M. In Heavy Metals in the Environment; Sarkar, B., ed., Marcel Dekker: New York, 2002, p. 349.

3. Preston J. S.; Hydrometallurgy 1983, 10, 187.

4. Zhang, P.; Yokoyama, T.; Suzuki, T. M.; Inoue, K.; Hydrometallurgy 2001, 61, 223.

5. Cerpa, A.; Alguacil, F. J.; J. Chem. Technol. Biotechnol. 2004, 79, 455

6. Sastre, A. M.; Kumar, A.; Shukla, J. P.; Singh, R. K.; Sep. Purif. Methods 1998, 27, 213 and references therein.

7. Hernández Cruz, L.; Lapidus, G. T.; Carrillo-Romero F.; Hydrometallurgy 1998, 48, 265.

8. de Gyves, J.; Rodriguez de San Miguel, E.; Ind. Eng. Chem. Res. 1999, 38, 2182 and references therein.

9. Alguacil, F. J.; Alonso, M.; Sastre, A. M.; Kumar, A. In Recent Research and Developments in Chemical Engineering; Pandalai, S. G., ed., Transworld Research Network: Trivandrum, 1993, vol. 5, p.83 and references therein.

10. Fernandez, L.; Aparicio, J.; Muhammed, M.; J. Membr. Sci. 1986, 27, 77.

11. Szymanowsky, J.; Hydroxyoximes and Copper Hydrometallurgy, CRC Press: Boca Raton, 1993.

12. Alguacil, F. J.; Rev. Metal. MADRID 2002, 38, 205.

13. Alguacil, F. J.; Alonso, M.; Sastre, A. M.; Chem. Eng. J. 2002, 85, 265

14. Alguacil, F. J.; Solvent Extr. Ion Exch. 2003, 21, 841.

15. Hill, C.; Dozol, J. F.; Rouquette, H.; Eymards, S.; Tournois, B.; J. Membr. Sci. 1996, 114, 73.

16. Alguacil, F. J.; Alonso, M.; Hydrometallurgy 2004, 74, 195 and references therein.

Received: October 25, 2005

Published on the web: June 12, 2006 